\title{
Human bronchial smooth muscle cells in culture produce stem cell factor
}

\author{
O. Kassel*, F. Schmidlin*, C. Duvernelle*, B. Gasser, G. Massard*, N. Frossard*
}

Human bronchial smooth muscle cells in culture produce stem cell factor. O. Kassel, F. Schmidlin, C. Duvernelle, B. Gasser, G. Massard, N. Frossard. CERS Journals Ltd 1999. ABSTRACT: A mast cell infiltration of the bronchial smooth muscle layer has been reported in patients sensitized to common allergens. Stem cell factor (SCF) is a chemotactic and survival factor for mast cells. SCF is expressed as a soluble (sSCF) and a membrane-bound ( $\mathrm{mSCF}$ ) form, after alternative splicing of the exon encoding the proteolytic cleavage site. SCF expression by human bronchial smooth muscle cells in culture was evaluated, comparing it to that of human lung fibroblasts in culture.

sSCF released in the culture supernatant was assessed by an enzyme-linked immunosorbent assay. Total SCF messenger ribonucleic acid (mRNA) was measured by competitive polymerase chain reaction (PCR) after reverse transcription. Expression of the two forms of SCF mRNA was assessed by PCR, with primers spanning the alternatively spliced exon.

Smooth muscle cells produced sSCF $\left(21.9 \pm 2.6 \mathrm{pg} \cdot \mathrm{mL}^{-1}\right)$, although at lower levels than fibroblasts $\left(35.9 \pm 3.5 \mathrm{pg} \cdot \mathrm{mL}^{-1}\right)$; the expression of total SCF mRNA was also at lower levels than in fibroblasts $(8.6 \pm 0.2$ and $19.0 \pm 2.0$ amol-fmol glyceraldehyde 3-phosphate dehydrogenase complementary deoxyribonucleic acid $^{-1}$, respectively). However, smooth muscle cells expressed proportionally more (1.7-fold) mSCF mRNA than did fibroblasts.

In conclusion, this study shows that bronchial smooth muscle cells express stem cell factor, with a relatively high expression of membrane-bound stem cell factor. This might be related to the presence of mast cells within the bronchial smooth muscle layer, i.e. at the site of bronchoconstriction, with possible implications in the pathophysiology of asthma.

Eur Respir J 1999; 13: 951-954.

Stem cell factor (SCF), also called Kit ligand, steel factor, and mast cell growth factor, is the ligand of the c-kit proto-oncogene product [1]. SCF is expressed in two forms, soluble (sSCF) and membrane-bound (mSCF), after alternative splicing of the sixth exon, which encodes a proteolytic cleavage site [2]. This protein is a pluripotent growth factor involved in the early stages of haematopoiesis and in the development and function of other cell types, including germ cells and melanocytes. It is also an important growth factor for human mast cells [3]: in vitro it induces proliferation and differentiation of immature mast cells from bone marrow CD34+ progenitor cells [4]; it is involved in mast cell survival by inhibiting their apoptosis [5]; and it is a potent chemotactic factor for mast cells [6]. SCF also induces mast cell hyperplasia in vivo after subcutaneous administration in humans [7]. It might therefore be involved in many diseases associated with a local increase in the number of mast cells, such as asthma $[8,9]$. SCF is produced by various cells of the bronchial mucosa, including bronchial epithelial cells [10] and bronchial fibroblasts [11].

Recently, mast cell infiltration of the smooth muscle layer of bronchi in patients sensitized to common allergens has been reported [12]. SCF expression has previously
*INSERM U425, Neuroimmunopharmacologie Pulmonaire, Faculté de Pharmacie, BP24, Illkirch Cedex, France. ${ }^{+}$Institut $\mathrm{d}^{\prime}$ Anatomie Pathologique and Service de Chirurgie Thoracique, Hôpitaux Universitaires de Strasbourg, France.

Correspondence: O. Kassel INSERM U425

Neuroimmunopharmacologie Pulmonaire Faculté de Pharmacie, BP24 67401 Illkirch Cedex

France

Fax: 33388678638

Keywords: Asthma

mast cells

smooth muscle

stem cell factor

Received: January 121999

Accepted after revision March 51999 been reported in aortic [13] and myometrial [14] smooth muscle cells. This study investigated whether SCF is also expressed by human bronchial smooth muscle cells in culture, and compared this expression to that of human lung fibroblasts in culture.

\section{Methods}

\section{Cell culture}

Commercially available human bronchial smooth muscle cells in primary culture (Clonetics Corp., San Diego, CA, USA) and human lung fibroblasts derived from macroscopically normal human lung tissue by the explant technique were cultured as previously described $[15,16]$. Smooth muscle cells and fibroblasts were characterized by immunocytochemistry using, respectively, an antismooth muscle $\alpha$-actin antibody (Sigma Chemical Co., St Louis, MO, USA), and an anti-fibroblast monoclonal antibody (5B5) that reacted with the $\beta$-subunit of prolyl 4-hydroxylase (Dako, Trappes, France). The state of fibroblasts was also characterized by their absence of smooth muscle $\alpha$-actin expression. 
Fibroblasts and smooth muscle cells at passage 5-7 were cultured in the same standardized condition to allow comparison of SCF expression between the two cell types. Culture medium contained DMEM/F12 supplemented with $10 \%$ foetal calf serum (FCS), $50 \mathrm{U} \cdot \mathrm{mL}^{-1}$ penicillin, and $50 \mu \mathrm{g} \cdot \mathrm{mL}^{-1}$ streptomycin, until confluence. Quiescence was induced by reducing the FCS content to $0.3 \%$ for $24 \mathrm{~h}$. Cells were cultured further in fresh medium containing $0.3 \% \mathrm{FCS}$ for $24 \mathrm{~h}$. Supernatants were removed and stored at $-70^{\circ} \mathrm{C}$ until assayed for sSCF levels by an enzyme-linked immunosorbent assay (ELISA), and cells were used for ribonucleic acid (RNA) extraction. The same cell cultures were used for the ELISA and polymerase chain reaction $(\mathrm{PCR})$ measurements.

\section{SCF ELISA}

Immunoreactive sSCF was quantified by a sensitive ELISA procedure as previously described [16], using a capture anti-human SCF monoclonal antibody (clone 13306.6; R\&D Systems Europe, Abingdon, UK), and a biotinylated detection anti-human SCF polyclonal antibody (R\&D Systems Europe), revealed by Extravidin $(\mathbb{R}$-horseradish peroxidase (Sigma) and a 3,3',5,5'-tetramethylbenzidine liquid substrate system (Sigma).

\section{Extraction of total RNA and reverse transcription}

Total RNA was extracted using TriReagent ${ }^{\mathrm{TM}}$ (Molecular Research Center, Cincinnati, OH, USA), and reverse transcribed using ribonuclease (RNase) $\mathrm{H}$ minus-Moloney leukaemia virus reverse transcriptase, as previously described [16].

\section{Quantification of total SCF complementary deoxyribo- nucleic acid by competitive PCR}

An aliquot $(1 \mu \mathrm{L})$ of a 1:20 dilution of the reverse transcription (RT) product was amplified by PCR in $1 \times$ PCR buffer $(50 \mathrm{mM} \mathrm{KCl}, 10 \mathrm{mM}$ Tris-HCl, $\mathrm{pH} 8.3$ ) containing $1.5 \mathrm{mM} \mathrm{MgC1} 1_{2}, 0.2 \mathrm{mM}$ deoxyribonucleoside triphosphate (dNTP), $10 \mathrm{pmol}$ of each primer (sense primer: 5'-TGGATAAGCGAGATGGTAGT-3'; antisense: 5'-TTTTCTTTCACGCACTCCAC-3') and 2 U Taq deoxyribonucleic acid (DNA) polymerase (Promega, Madison, WI, USA) in a $50 \mu \mathrm{L}$ final volume, for 40 cycles $(60 \mathrm{~s}$ at $94^{\circ} \mathrm{C}, 30 \mathrm{~s}$ at $50^{\circ} \mathrm{C}$, and $60 \mathrm{~s}$ at $72^{\circ} \mathrm{C}$ ), in the presence of increasing amounts of SCF competitor complementary DNA (cDNA; 0.02, 0.04, 0.08, 0.2, 0.4 and 0.8 amol) [16]. SCF competitor cDNA has been constructed using a PCR strategy [16], amplifying SCF cDNA with primers (antisense primer described above, sense composite primer: $5^{\prime}$-sense primer-CTTCGTGACAAGTTTTCAAA-3') leading to a 25 base pair (bp) deletion in the SCF cDNA sequence.

Quantification of glyceraldehyde 3-phosphate dehydrogenase (GAPDH) cDNA by competitive PCR was used to normalize results. An aliquot $(1 \mu \mathrm{L})$ of a 1:200 dilution of the RT product was amplified by PCR in $1 \times$ PCR buffer containing $2.5 \mathrm{mM} \mathrm{MgCl}, 0.2 \mathrm{mM}$ dNTP, 20 pmol of each primer (sense: $5^{\prime}$-GGTGAAGGTCGGAGTCAACGGA-3'; antisense: 5'-GAGGGATCTCGCTCCTGGAAGA-3') and $1 \mathrm{U} \mathrm{Taq}$ polymerase in a $50 \mu \mathrm{L}$ final volume, for 30 cycles $\left(60 \mathrm{~s}\right.$ at $96^{\circ} \mathrm{C}, 60 \mathrm{~s}$ at $60^{\circ} \mathrm{C}$, and $60 \mathrm{~s}$ at $72^{\circ} \mathrm{C}$ ), in the presence of increasing amounts of GAPDH com- petitor cDNA $(0.04,0.08,0.2,0.4,0.8$ and 2 amol). GAPDH competitor cDNA was constructed by PCR using primers (antisense primer described above, sense composite primer: 5'-sense primer-CCAGGGCTTTTAACTCTGG-3') leading to a 25 bp deletion in the GAPDH cDNA sequence [16].

\section{Expression of the two forms of SCF messenger RNA}

PCR amplification was performed with primers spanning the alternatively spliced sixth exon (sense primer: $5^{\prime}$ TGGATAAGCGAGATGGTAGT-3'; antisense: 5'-AGCCACAATTTACACTTCTT-3') to generate a 627-bp for SSCF cDNA, and a 544-bp PCR product for mSCF cDNA, as previously described [16]. An aliquot $(1 \mu \mathrm{L})$ of a 1:20 dilution of the RT product was amplified by PCR in $1 \times$ PCR buffer containing $2.5 \mathrm{mM} \mathrm{MgCl} 2,0.1 \mathrm{mM}$ dNTP, 10 pmol of each primer, and $1 \mathrm{U} \mathrm{Taq}$ polymerase in a $50 \mu \mathrm{L}$ final volume, for 40 cycles $\left(60 \mathrm{~s}\right.$ at $94^{\circ} \mathrm{C}, 30 \mathrm{~s}$ at $55^{\circ} \mathrm{C}$, and $60 \mathrm{~s}$ at $72^{\circ} \mathrm{C}$ ).

\section{PCR products analysis}

PCR products $(15 \mu \mathrm{L})$ were denatured $\left(99^{\circ} \mathrm{C}, 10 \mathrm{~min}\right)$ in the presence of $50 \%$ deionized formamide, and resolved by electrophoresis on denaturating $50 \%$ urea-17\% formamide-polyacrylamide $(10 \%$ for competitive PCR; $6 \%$ for the two forms of SCF messenger RNA (mRNA) gels in parallel with a 100 bp DNA ladder (Life Technologies, Cergy, Pontoise, France)). Gels were stained with ethidium bromide, digitalized under ultraviolet light using a high performance CCD camera (Cohu Inc., San Diego, CA, USA), and analysed using the public domain NIH Image program [16].

For determination of SCF cDNA, ratios of PCR products of SCF to SCF competitor cDNAs and GAPDH to GAPDH competitor cDNAs were calculated for each concentration of competitor, and plotted against the concentration in order to calculate the initial concentrations of $\mathrm{SCF}$ and GAPDH cDNAs at ratios equal to 1 . Results were expressed as amol SCF cDNA.fmol GAPDH cDNA $^{-1}$.

To analyse the expression of the two forms of SCF mRNA, the ratio of $\mathrm{mSCF} / \mathrm{sSCF}$ and the proportion of mSCF over total SCF PCR products were calculated.

\section{Statistical analysis}

All results are expressed as means \pm SEM for the number of experiments. Comparisons of the expression of SCF protein and mRNA between smooth muscle cells and fibroblasts were made with the nonparametric Mann-Whitney U-test. A p-value $<0.05$ was considered significant.

\section{Results}

Expression of SCF protein and mRNA by human smooth muscle cells

Smooth muscle cells produced immunoreactive soluble SCF. Figure 1a shows that SSCF production by smooth muscle cells is lower than fibroblasts cultured in the same conditions $\left(21.9 \pm 2.6\right.$ and $35.9 \pm 3.5 \mathrm{pg} \cdot \mathrm{mL}^{-1}$, respectively, $\mathrm{n}=10, \mathrm{p}<0.05)$. Total SCF mRNA was also expressed at lower levels by smooth muscle cells than by fibroblasts (SCF cDNA: $8.6 \pm 0.2$ and 19.0 $\pm 2.0 \mathrm{amol} \cdot \mathrm{fmol} \mathrm{GAPDH}$ cDNA $^{-1}$, respectively, $n=5, p<0.05$ ) (fig. $1 \mathrm{~b}$ ). 

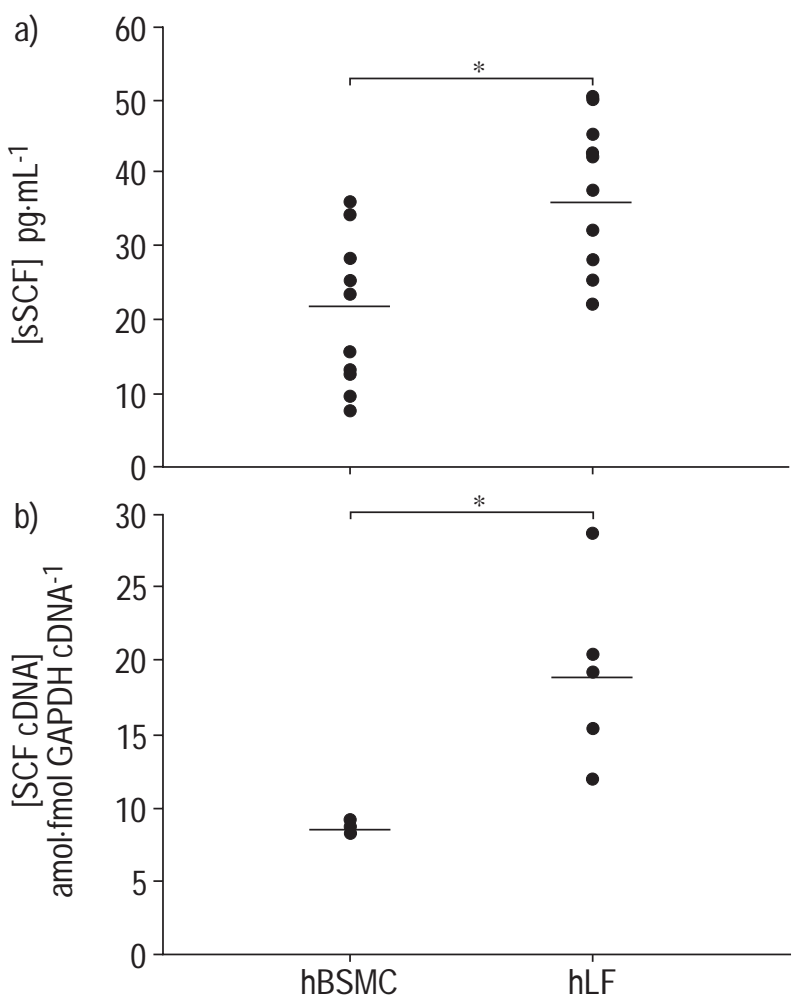

Fig. 1. - Stem cell factor (SCF) protein and messenger ribonucleic acid (mRNA) expression by human bronchial smooth muscle cells (hBSMC) and human lung fibroblasts (hLF) in culture. Confluent quiescent cells were cultured for $24 \mathrm{~h}$ in $0.3 \%$ foetal calf serum-containing DMEM/ F12. a) Immunoreactive soluble SCF (sSCF) levels were assessed in the culture supernatant by a sandwich enyme-linked immunosorbent assay. *: $p<0.05$ compared with sSCF released by fibroblasts $(n=10)$. b) Total RNA was extracted and reverse transcribed, and SCF complementary deoxyribonucleic acid (cDNA) was quantified by competitive polymerase chain reaction. Results were normalized to reduced glyceraldehydephosphate dehydrogenase (GAPDH) cDNA. *: p<0.05 compared with $\mathrm{SCF}$ cDNA levels obtained from fibroblasts $(\mathrm{n}=5)$. Horizontal bars represent the means.

\section{Expression of both forms of SCF mRNAs by human bronchial smooth muscle cells}

Smooth muscle cells expressed both of the mRNAs that encode SCF (fig. 2a), with a predominance of the long transcript encoding sSCF, and only a small amount of the short transcript which encodes mSCF. As compared to fibroblasts, smooth muscle cells produced a higher proportion of mSCF mRNA than did fibroblasts $(6.3 \pm 0.2 \%$ and $3.7 \pm 0.2 \%$ of total SCF mRNA, for smooth muscle cells and fibroblasts, respectively, $n=5, p<0.01$ ) (fig. $2 b$ ).

\section{Discussion}

This study reports evidence that a mast cell growth factor, SCF, is produced by human bronchial smooth muscle cells in culture. Recently, the hypothesis of functional interactions between mast cells and the smooth muscle in asthma has been reinforced by reports that bronchi from patients sensitized to common allergens show mast cell infiltration of the smooth muscle layer [12]. SCF plays a role in the regulation of mast cell development, survival, reactivity, and function in health and disease, both in vitro and in vivo [3], and may be particularly relevant to the a)

hBSMC
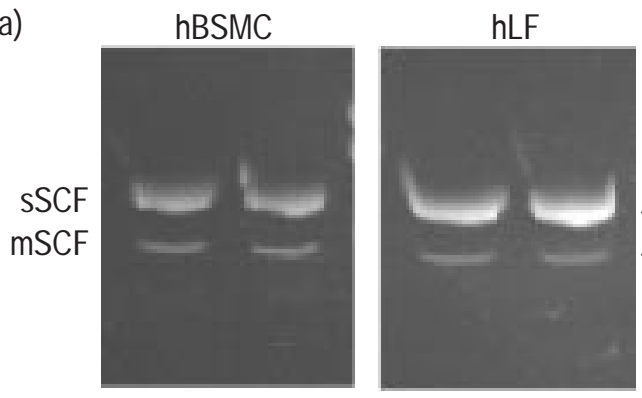

$-627 \mathrm{bp}$

$-544 \mathrm{bp}$

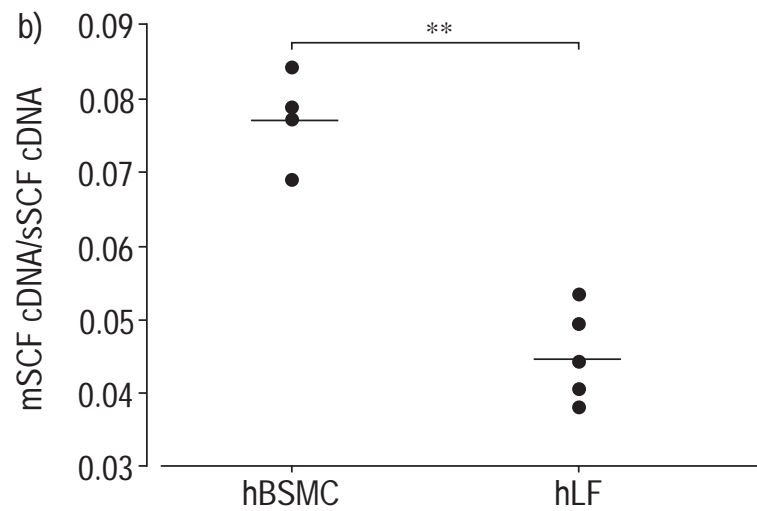

Fig. 2. - Human bronchial smooth muscle cells (hBSMC) and human lung fibroblasts (hLF) in culture express both forms of stem cell factor (SCF) messenger ribonucleic acid. Confluent quiescent cells were cultured for $24 \mathrm{~h}$ in $0.3 \%$ foetal calf serum-containing DMEM/F12. Total ribonucleic acid (RNA) was extracted and reverse transcribed, and complementary deoxyribonucleic acids (cDNAs) were amplified by polymerase chain reaction (PCR) using primers leading to 627 and 544 base pair (bp) products for soluble SCF (sSCF) and membrane-bound SCF (mSCF) cDNAs, respectively. a) PCR products were resolved by gel electrophoresis. b) The density of each band was analysed, and ratios of mSCF cDNA to SSCF cDNA are presented. **: $\mathrm{p}<0.01$ compared with the ratio obtained from fibroblasts $(n=5)$. Horizontal bars represent the means.

pathophysiology of asthma [17]. The concentrations of SCF that were measured in the supernatants of smooth muscle cells in the present study are compatible with a chemotactic effect on mast cells, occurring in vitro at SCF doses as low as $10 \mathrm{ng} \cdot \mathrm{mL}^{-1}[6]$. Hence, this finding raises the possibility of SCF production by smooth muscle cells. Such an expression in the smooth muscle layer of sensitized patients, which needs to be addressed further, might be related to the recruitment and survival of mast cells infiltrating the smooth muscle layer of sensitized bronchi, as shown recently [12].

A second interesting feature of these results is the quantitative difference in the amounts of the mSCF mRNA expressed by smooth muscle cells and fibroblasts. SSCF mRNA was the predominant transcript, as reported for several other cell types, including lung fibroblasts [18]. However, smooth muscle cells, although producing lower amounts of total SCF than fibroblasts, expressed proportionally more mSCF mRNA (1.7-fold). Such a difference, if also observed at the protein level, might have important functional consequences. The two forms of SCF may indeed have different functions, as suggested by studies of homozygous mice for the Steel-Dickie allele. These mice produce biologically active $\mathrm{sSCF}$, but no $\mathrm{mSCF}$, and present a profound deficiency of mast cells [19]. These 
results suggest that $\mathrm{mSCF}$ is more important than $\mathrm{sSCF}$ for the in vivo development of mast cells. mSCF also acts as an adhesion molecule for mast cells [20]. Because smooth muscle cells produce proportionally more $\mathrm{mSCF}$ mRNA, and presumably protein, than do fibroblasts, the contacts between mast cells and smooth muscle cells within the bronchial wall might be particularly intimate and lead to more sustained interaction.

Moreover, a local production of SCF by bronchial smooth muscle may also play some role in the local activation of mast cells [12]. SCF indeed activates mast cells in isolated human bronchi [21], and greatly enhances antigen-induced activation of human lung mast cells in vitro $[22,23]$. Moreover, in allergen-challenged sensitized mice, an increased SCF production contributes to mast cell activation, since its blockade decreases it [17]. If an increased expression of SCF occurs in the airways of asthmatic patients, then local SCF production by smooth muscle cells in the bronchus might help potentiate mast cell activation at the site of bronchoconstriction.

In conclusion, human bronchial smooth muscle cells in culture produce stem cell factor messenger ribonucleic acid and protein, and proportionally more membrane-bound stem cell factor messenger ribonucleic acid than human lung fibroblasts. Stem cell factor production by smooth muscle cells within the bronchus of asthmatic patients, which now needs to be addressed, might be relevant to the increased activation of mast cells, and to their increased number in the smooth muscle layer of sensitized patients [12]. These findings reinforce the hypothesis that the airway smooth muscle has an immune role, orchestrating a local inflammatory reaction, by recruiting and/or regulating the functions of infiltrated inflammatory cells at the site of bronchoconstriction.

\section{References}

1. Martin FH, Suggs SV, Langley KH, et al. Primary structure and functional expression of rat and human stem cell factor DNAs. Cell 1990; 63: 203-211.

2. Anderson DM, Williams DE, Tushinski R, et al. Alternate splicing of mRNAs encoding human mast cell growth factor and localization of the gene to chromosome 12q22q24. Cell Growth Differ 1991; 2: 373-378.

3. Galli SJ, Tsai M, Wershil BK, et al. The effects of stem cell factor, the ligand for the c-kit receptor, on mouse and human mast cell development, survival, and function. In: Kitamura Y, Yamamoto S, Galli SJ, Greaves MW, eds. Biological and Molecular Aspects of Mast Cell and Basophil Differentiation and Function. New York, Raven Press, 1995; pp. 1-11.

4. Kirshenbaum AS, Goff JP, Kessler SW, Mican JM, Zsebo KM, Metcalfe DD. Effect of IL-3 and stem cell factor on the appearance of human basophils and mast cells from CD34+ pluripotent progenitor cells. J Immunol 1992; 148: 772-777.

5. Iemura A, Tsai M, Ando A, Wershil BK, Galli SJ. The ckit ligand, stem cell factor, promotes mast cell survival by suppressing apoptosis. Am J Pathol 1994; 144: 321-328.

6. Nilsson G, Butterfield JH, Nilsson K, Siegbahn A. Stem cell factor is a chemotactic factor for human mast cells. $J$ Immunol 1994; 153: 3717-3723.

7. Costa JJ, Demetri GD, Harrist TJ, et al. Recombinant human stem cell factor (kit ligand) promotes human mast cell and melanocyte hyperplasia and functional activation in vivo. J Exp Med 1996; 183: 2681-2686.

8. Pesci A, Foresi A, Bertorelli G, Chetta A, Oliveri D. Histochemical characteristics and degranulation of mast cells in epithelium and lamina propria of bronchial biopsies from asthmatic and normal subjects. Am Rev Respir Dis 1993; 147: 684-689.

9. Bradding P, Roberts JA, Britten KM, et al. Interleukin-4, interleukin-5, and interleukin-6 and tumor necrosis factoralpha in normal and asthmatic airways: evidence for the human mast cell as a source of these cytokines. $\mathrm{Am} \mathrm{J}$ Respir Cell Mol Biol 1994; 10: 471-480.

10. Wen LP, Fahrni JA, Matsui S, Rosen GD. Airway epithelial cells produce stem cell factor. Biochim Biophys Acta 1996; 1314: 183-186.

11. Zhang S, Howarth PH, Roche WR. Cytokine production by cell cultures from bronchial subepithelial myofibroblasts. J Pathol 1996; 180: 95-101.

12. Ammit AJ, Bekir SS, Johnson PRA, Hughes JM, Armour $\mathrm{CL}$, Black JL. Mast cell numbers are increased in the smooth muscle of human sensitized isolated bronchi. Am J Respir Crit Care Med 1997; 155: 1123-1129.

13. Miyamoto T, Sasaguri Y, Sasaguri T, et al. Expression of stem cell factor in human aortic endothelial and smooth muscle cells. Atherosclerosis 1997; 129: 207-213.

14. Mori A, Nakayama K, Suzuki J, Nikaido T, Isobe M, Fujii $\mathrm{S}$. Analysis of stem cell factor for mast cell proliferation in the human myometrium. Mol Hum Reprod 1997; 3: 411-418.

15. Schmidlin F, Scherrer D, Daeffler L, Bertrand C, Landry Y, Gies JP. Interleukin-1 beta induces bradykinin $\mathrm{B}_{2}$ receptor gene expression through a prostanoid cyclic AMPdependent pathway in human bronchial smooth muscle cells. Mol Pharmacol 1998; 53: 1009-1015.

16. Kassel O, Schmidlin F, Duvernelle C, De Blay F, Frossard N. Up- and down-regulation by glucocorticoids of the constitutive expression of the mast cell growth factor stem cell factor by human lung fibroblasts in culture. Mol Pharmacol 1998; 54: 1073-1079.

17. Lukacs NW, Kunkel SL, Strieter RM, et al. The role of stem cell factor (c-kit ligand) and inflammatory cytokines in pulmonary mast cell activation. Blood 1996; 87: 2262 2268.

18. Heinrich MC, Dooley DC, Freed AC, et al. Constitutive expression of steel factor gene by human stromal cells. Blood 1993; 82: 771-783.

19. Brannan CI, Lyman SD, Williams DE, et al. Steel-Dickie mutation encodes a c-kit ligand lacking transmembrane and cytoplasmic domains. Proc Natl Acad Sci USA 1991; 88: 4671-4674.

20. Adachi $\mathrm{S}$, Tsujimura $\mathrm{T}$, Jippo $\mathrm{T}$, et al. Inhibition of attachment between cultured mast cells and fibroblasts by phorbol 12-myristate 13-acetate and stem cell factor. Exp Hematol 1995; 23: 58-65.

21. Undem BJ, Lichtenstein LM, Hubbard WC, Meeker S, Ellis JL. Recombinant stem cell factor-induced mast cell activation and smooth muscle contraction in human bronchi. Am J Respir Cell Mol Biol 1994; 11: 646-650.

22. Bischoff SC, Dahinden CA. c-kit ligand: a unique potentiator of mediator release by human lung mast cells. $J$ Exp Med 1992; 175: 237-244.

23. Okayama Y, Petit-Frere C, Kassel O, et al. IgE-dependent expression of mRNA for IL-4 and IL-5 in human lung mast cells. J Immunol 1995; 155: 1796-1808. 